\title{
Test Results from the Idaho National Laboratory of the NASA Bi-Supported Cell Design
}

\section{IMECE 2009}

C. Stoots

J. O'Brien

T. Cable

November 2009

The INL is a

U.S. Department of Energy

National Laboratory

operated by

Battelle Energy Alliance

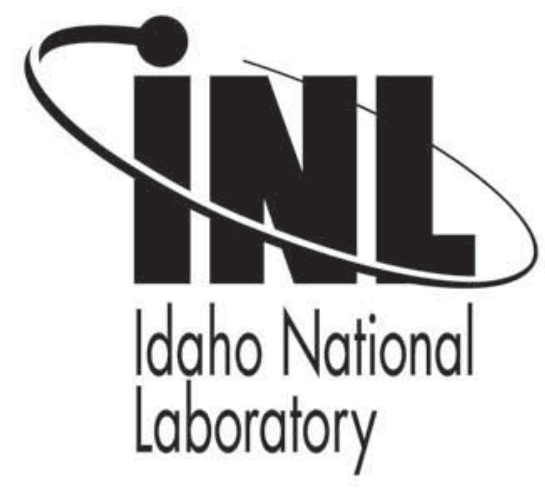

This is a preprint of a paper intended for publication in a journal or proceedings. Since changes may be made before publication, this preprint should not be cited or reproduced without permission of the author. This document was prepared as an account of work sponsored by an agency of the United States Government. Neither the United States Government nor any agency thereof, or any of their employees, makes any warranty, expressed or implied, or assumes any legal liability or responsibility for any third party's use, or the results of such use, of any information, apparatus, product or process disclosed in this report, or represents that its use by such third party would not infringe privately owned rights. The views expressed in this paper are not necessarily those of the United States Government or the sponsoring agency. 
IMECE2009-11646

\title{
TEST RESULTS FROM THE IDAHO NATIONAL LABORATORY OF THE NASA BI- SUPPORTED CELL DESIGN
}

\author{
C. STOOTS \\ Idaho National Laboratory \\ Idaho Falls, Idaho, USA \\ carl.stoots@inl.gov
}

\author{
J. O'BRIEN \\ Idaho National Laboratory \\ Idaho Falls, Idaho, USA \\ james.obrien@inl.gov
}

\author{
T. CABLE \\ NASA Glenn Research Center \\ Cleveland, Ohio, USA \\ Thomas.L.Cable@grc.nasa.gov
}

\begin{abstract}
The Idaho National Laboratory has been researching the application of solid-oxide fuel cell technology for large-scale hydrogen production. As a result, the Idaho National Laboratory has been testing various cell designs to characterize electrolytic performance. NASA, in conjunction with the University of Toledo, has developed a new cell concept with the goals of reduced weight and high power density. This paper presents results of the INL's testing of this new solid oxide cell design as an electrolyzer. Gas composition, operating voltage, and other parameters were varied during testing. Results to date show the NASA cell to be a promising design for both high power-to-weight fuel cell and electrolyzer applications.
\end{abstract}

\section{INTRODUCTION}

Conventional world oil production will eventually peak and subsequently decline. Predictions of when this peak will occur are controversial and difficult to make due to geological complexities, measurement problems, pricing variations, demand elasticity, and political influences (Hirsh et al., 2005). Nonetheless, the impact of peak oil could be tremendous and unprecedented. In the present, demands upon existing reserves and production capacity are growing, primarily due to industrializing nations such as China and India (Sandalow, 2008). These issues plus instabilities in crude oil prices, shrinking new discoveries, and worries over crude supply disruptions have made energy security an important topic. Finally, there are the climate change aspects of oil usage. Most of the United State's energy-related $\mathrm{CO}_{2}$ emissions come from oil consumption.

These issues have been driving the development of a noncarbon, renewable, $\mathrm{H}_{2}$-based energy infrastructure (Scott, 2008). Plus, the demand for $\mathrm{H}_{2}$ has been increasing by $10 \%$ per year. The goals of a hydrogen-based energy economy are reduced oil consumption, foreign energy independence, and reduced greenhouse gas emissions. Since hydrogen is an energy carrier and not an energy source, attaining these goals is conditional upon development of suitable renewable energy sources and/or nuclear energy to power water-splitting technologies for carbon-free hydrogen production. Watersplitting for hydrogen production can be accomplished via high-temperature electrolysis or thermochemical processes, using high-temperature nuclear process heat and electricity. In order to achieve competitive efficiencies, both processes require high-temperature operation. High-temperature electrolytic water-splitting supported by nuclear process heat and electricity has the potential to produce hydrogen with an overall system efficiency near those of the thermochemical processes (Yildiz et al., 2008), but without the corrosive conditions of thermochemical processes and without the fossil fuel consumption and greenhouse gas emissions associated with hydrocarbon processes. The Idaho National Laboratory (INL) has been researching the use of solid-oxide fuel cell technology to electrolyze steam for large-scale nuclearpowered hydrogen production. The scope of activities includes computational fluid dynamics modeling, process flow sheet analyses, and experimental testing. Scales of experimental testing extend from $\sim 2$ watt button cell tests to $15 \mathrm{~kW}$ multistack tests.

The United States Government retains, and by accepting the article for publication, the publisher acknowledges that the United States Government retains, a non-exclusive, paid-up, irrevocable, worldwide license to publish or reproduce the published form of this work, or allow others to do so, for United States Government purposes. 


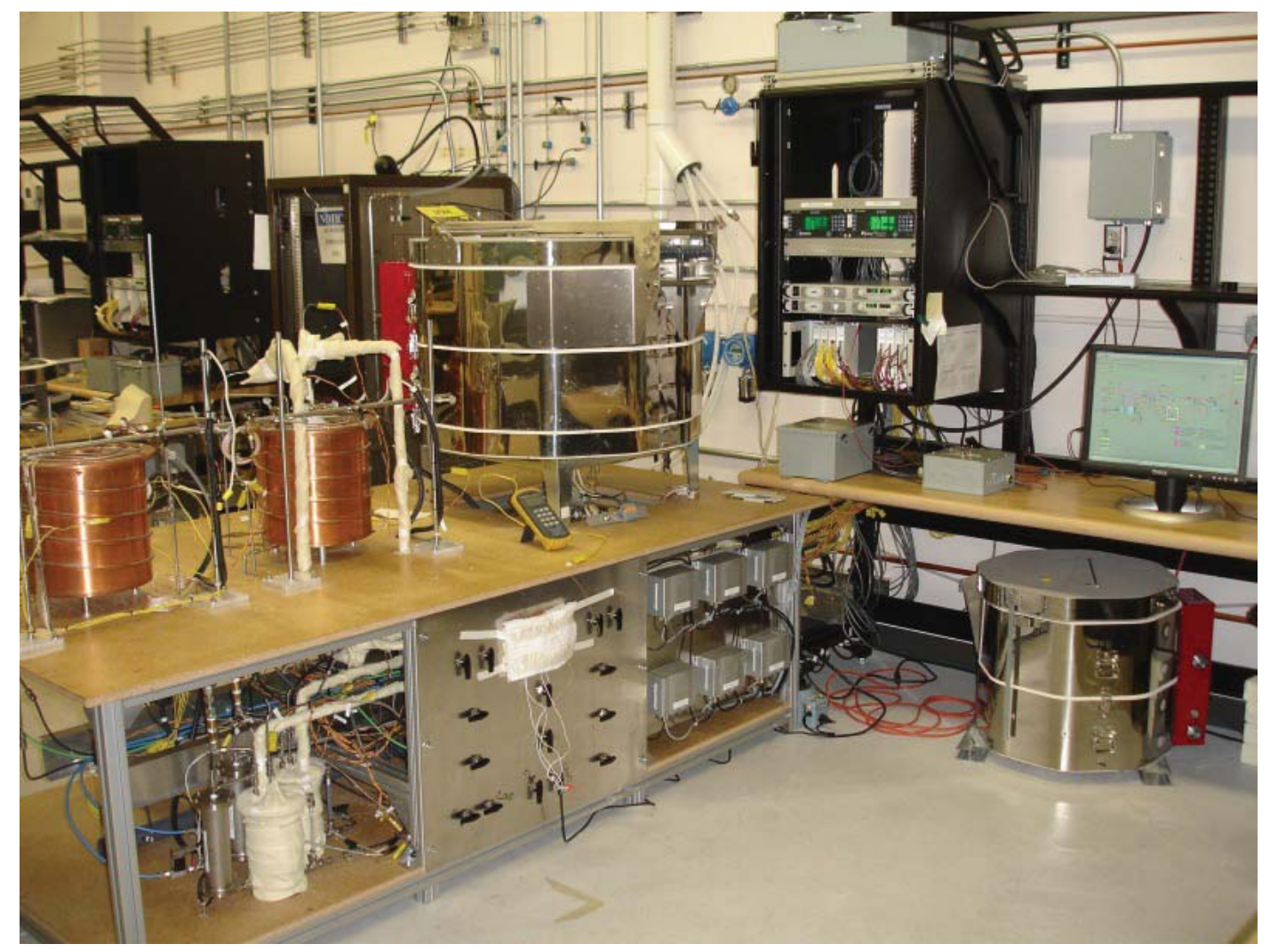

Figure 1. INL high-temperature electrolysis laboratory.

\section{CURRENT EXPERIMENTAL TESTING FACILITY}

A comprehensive discussion of the INL high temperature solid oxide electrolysis bench scale experiment is presented elsewhere (Stoots et al., 2009). This same facility is used for button cell testing as well as stack testing. A photograph of the test hardware is found in Fig. 1 and a schematic follows in Fig. 2.
Primary components include gas supply cylinders, mass-flow controllers, a humidifier, dewpoint measurement stations, high temperature furnace, and a solid oxide electrolysis cell. Nitrogen is used as an inert carrier gas. The use of a carrier gas allows for independent variation of both the partial pressures and the flow rates of the inlet steam and hydrogen while continuing to operate

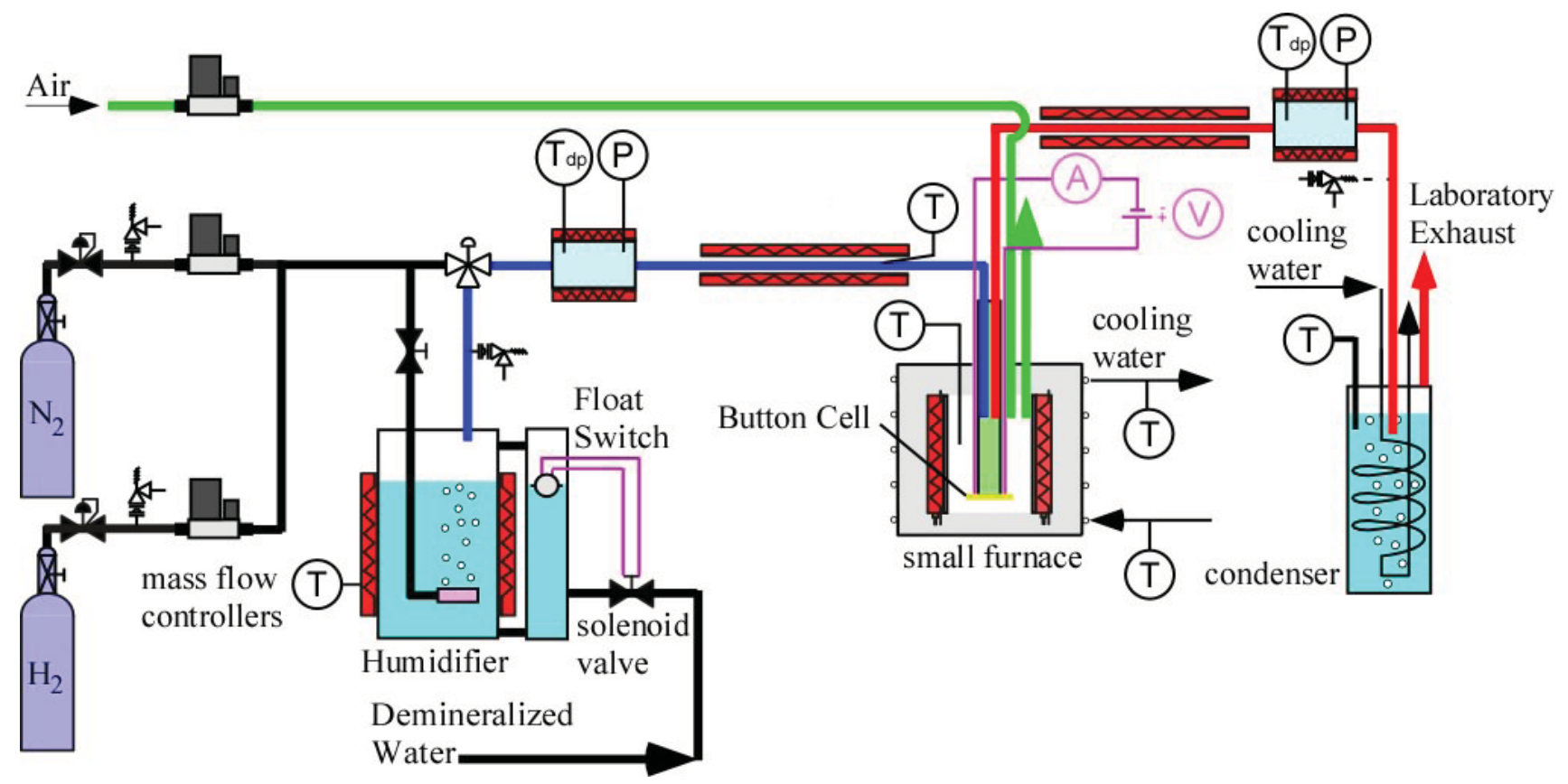

Figure 2. Schematic of one of INL button cell testing apparati. 


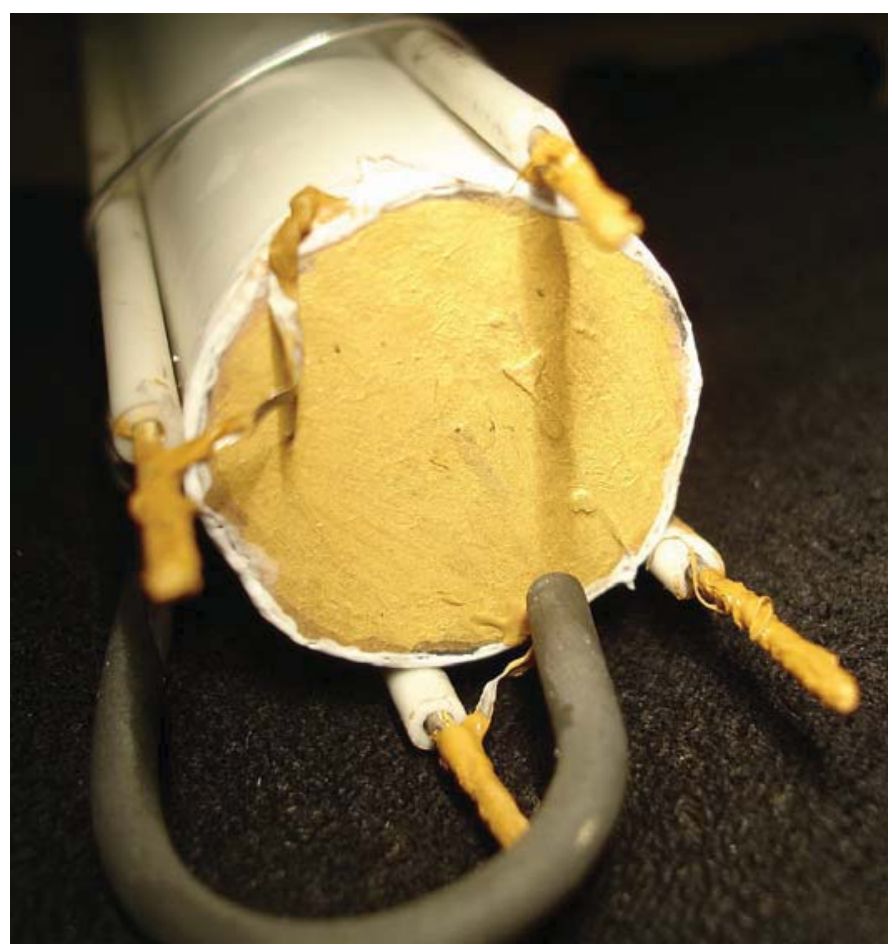

Figure 3. NASA button cell mounted on support tube..

near atmospheric pressure. The flow rates of nitrogen, hydrogen, and air are established by means of precision mass-flow controllers. Air flow to the stack is supplied by the shop air system, after passing through a two-stage extractor / dryer unit.

Downstream of the mass-flow controllers, nitrogen is mixed with smaller flows of hydrogen gas. Hydrogen is included in the inlet flow as a reducing gas in order to prevent oxidation of the Nickel cermet electrode material. The nitrogen / hydrogen gas mixture is mixed with steam by means of a heated humidifier. The humidifier water temperature is maintained at a constant setpoint value using computerized feedback control. The dewpoint temperature of the nitrogen / hydrogen / steam gas mixture exiting the humidifier is monitored continuously using a precision dewpoint sensor (Vaisala HMT330). Pressure is also measured at the dewpoint measurement stations using absolute pressure transducers. Local stream pressure information is required to determine the mole fraction of steam in the gas mixture at the dew point measurement station. Since the nitrogen and hydrogen flow rates are fixed by the mass flow controllers, and the steam partial pressure is fixed by the bath temperature, the complete inlet gas composition is precisely known at all times. All gas lines located downstream of the humidifier are heat-traced in order to prevent steam condensation. Gas line temperatures are monitored by thermocouples and controlled by means of computer-controlled SCRs.

The electrolysis product stream exiting the furnace is directed towards a second dewpoint sensor and then to a condenser through a heat-traced line. The condenser removes most of the residual steam from the exhaust. The final exhaust stream is vented outside the laboratory through the roof.
The rate of steam electrolysis is measured via two different, independent methods: 1) electrical current through the stack and 2) the measured change in inlet and outlet steam concentration as measured by the on-line dew point sensors.

For single-cell testing, an electrolysis button cell is bonded to the bottom of a zirconia tube (Fig. 3). During testing, the tube is suspended in one of the smaller furnaces. The active cell area is approximately $2.25 \mathrm{~cm}^{2}$ for the cell shown. A type$\mathrm{K}$ stainless-steel sheathed thermocouple is mounted on the tube and bent around in front of the button cell in order to allow for continuous monitoring of the button-cell temperature.

\section{CELL FABRICATION}

The NASA cell is structurally symmetrical, with both electrodes supporting the thin electrolyte and containing microchannels for gas diffusion, a bi-electrode supported cell or BSC. The electrodes are made by freeze-casting, a modified tape casting technique which creates the many micro-channels in the YSZ electrode green tape as shown in Fig. 4. In freezetape casting an aqueous or organic slip is cast across a freezing bed and micron size ice crystals start to form at the Mylar side of the tape. The micro-crystals increase in size and form continuous ice crystals that grow larger towards the top, creating a natural gradient in porosity in the green tape; the green tape is placed in a freeze dryer and the ice crystals are removed by sublimation in a vacuum, leaving the micro-

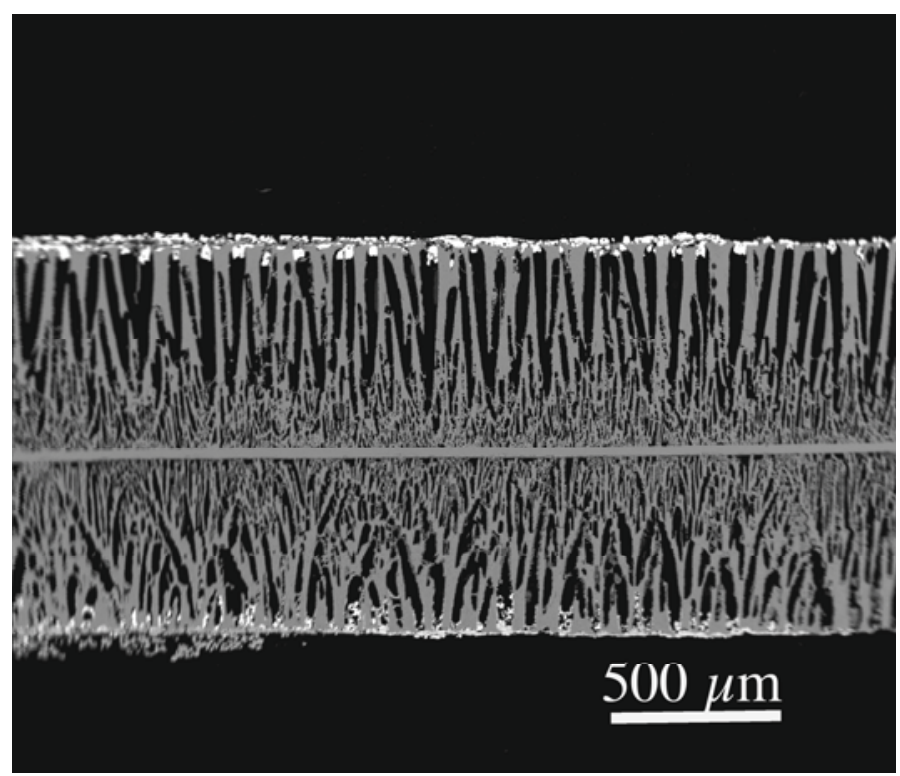

Figure 4. Cross section of a sintered BSC cell showing the thin YSZ (white) electrolyte in the center and the YSZ scaffolds, and the micro channels (black) formed by the ice crystals during freeze-casting, and then removed during freeze drying. The bright white at the top and bottom of the cell is Au ink.

channels behind for gas flow. Symmetrical cells are fabricated by taking two green parts cut from the same piece of green 
freeze-cast tape, depositing a thin electrolyte layer between the tapes, and laminating the tapes together with the small pores facing each other, forming the YSZ tri-layer as shown in Fig. 4. Cells, $2.54 \mathrm{~cm}$ O.D. (1") were prepared by firing the YSZ trilayers at high temperature, followed by infiltration of the electrodes. Ni-nitrate was used for the SOFC anode and stoichiometric solutions of nitrates for the LSF cathode. Cells were allowed to dry/solidify prior to heat treatment for decomposition of the nitrates into metals or metal oxides depending on the electrode. This infiltration procedure was performed multiple times on both the anode and cathode to achieve suitable electrodes. The cells were then bonded to the end of a 1" O.D. YSZ tube using a high temperature glass ceramic (Fig. 3).

A Pt wire was placed on both sides of the cell to read the voltage and then Ni-mesh was used on the $\mathrm{H}_{2}$ electrode and $\mathrm{Ag}$ mesh on the air electrode as current collectors; Au ink was used to attach the Pt wires for voltage measurement, and the other leads to the cells.

\section{SAMPLE BUTTON CELL TEST RESULTS}

A total of 7 NASA button cells have been tested to date at

TABLE I

Cell test conditions.

\begin{tabular}{|c|c|c|c|c|c|}
\hline Cell & $\begin{array}{c}\mathbf{H}_{2} \\
\text { Inlet } \\
\text { (sccm) }\end{array}$ & $\begin{array}{c}\mathbf{N}_{2} \\
\text { Inlet } \\
\text { (sccm) }\end{array}$ & $\begin{array}{c}\text { Inlet } \\
\text { Dew } \\
\text { Point T } \\
\text { (C) }\end{array}$ & $\begin{array}{c}\mathbf{H}_{2} \mathbf{O} \\
\text { Inlet } \\
\text { (sccm) }\end{array}$ & $\begin{array}{c}\text { Inlet } \\
\text { Mole } \\
\text { Fraction } \\
\mathbf{H}_{\mathbf{2}} \mathbf{O}\end{array}$ \\
\hline 1 & 63 & 350 & 50 & 70 & 0.14 \\
2 & 60 & 230 & 77 & 282 & 0.49 \\
3 & 60 & 300 & 60 & 110 & 0.23 \\
4 & 50 & 350 & 50 & 68 & 0.15 \\
5 & 50 & 350 & 50 & 70 & 0.15 \\
6 & 50 & 350 & 50 & 68 & 0.15 \\
7 & 50 & 350 & $50 / 62$ & $68 / 138$ & $0.17 / 0.35$
\end{tabular}

the INL. Three cells were tested in October of 2008, and four were tested in April of 2009. Between the two testing periods the testing apparatus was completely rebuilt and expanded, allowing simultaneous testing of two button cells and one stack. All testing was conducted at a furnace temperature of $850 \mathrm{C}$. Table 1 lists the various inlet conditions used for the cells. In the case of cell $\# 7$, testing was started with an inlet dew point of $50 \mathrm{C}$, but the inlet dew point was later increased to $62 \mathrm{C}$ to avoid issues of steam starvation and improve cell performance.

Figs. 5 and 6 represent results of a voltage sweep / polarization curve test for NASA cell 1. The VI curve and resulting area-specific-resistance (ASR) curve are shown in Fig. 5. The VI curve is relatively linear for current densities less than $0.6 \mathrm{~A} / \mathrm{cm}^{2}$. The non-linearity of the VI curve (and ASR curve) for higher current densities is indicative of steam starvation. At a current density of $0.6 \mathrm{~A} / \mathrm{cm}^{2}$, the steam utilization was only approximately $20 \%$. Starvation was not due to high steam utilization but due to the relatively low inlet steam flow rate.

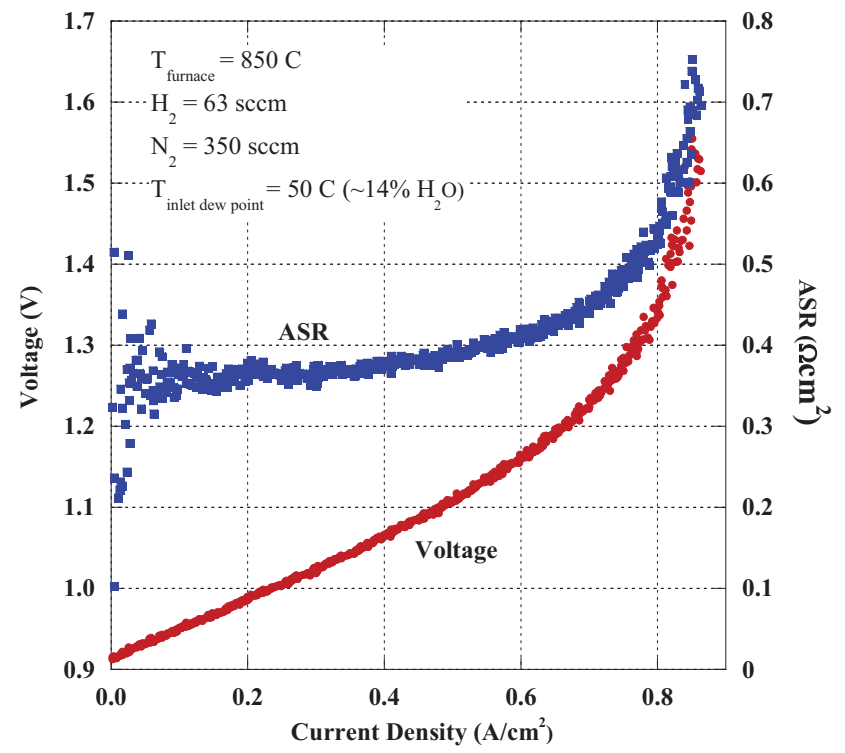

Figure 5. Polarization curve for first NASA cell tested.

Scatter in the ASR values at low current densities is due to difficulties in measuring extremely low current values.

Fig. 6 presents the inlet / outlet gas mixture dew point values as well as hydrogen production rates. Two different calculated hydrogen production rates are shown: hydrogen production estimated rate from the difference between outlet and inlet dew points, and hydrogen production rate estimated from the cell current (Faraday's Law). As the cell voltage and current increase, steam is consumed. The measured outlet dew point drops in value while the measurement of hydrogen production rate increases in value. The good agreement between the two independent measurements of hydrogen production rate indicates negligible cell leakage and no cell electrical shorting.

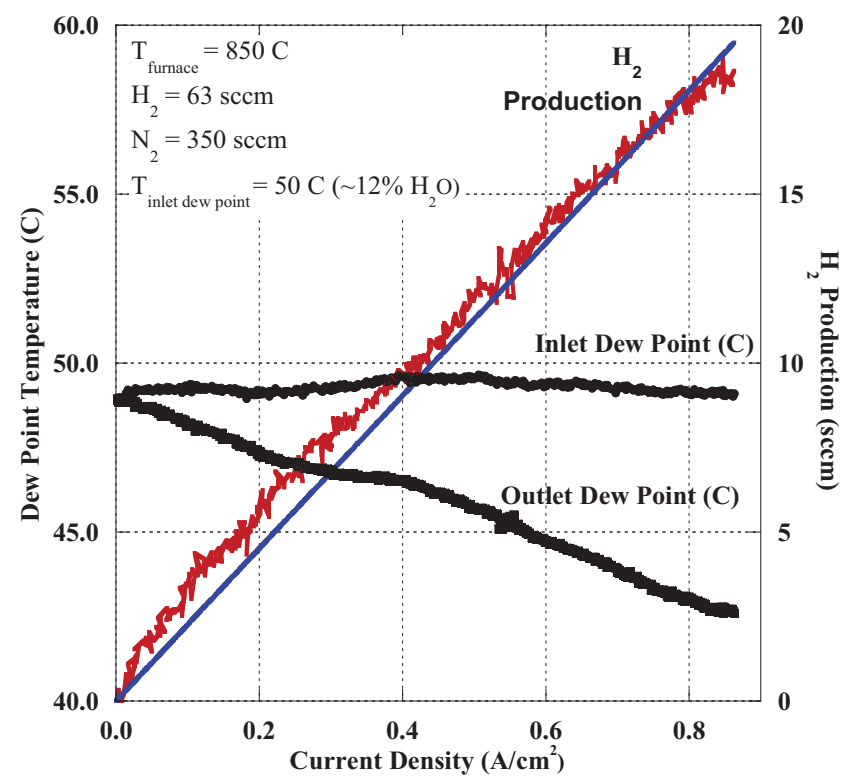

Figure 6. Dew points and $\mathrm{H}_{2}$ production rates for polarization curve in Fig. 5. 


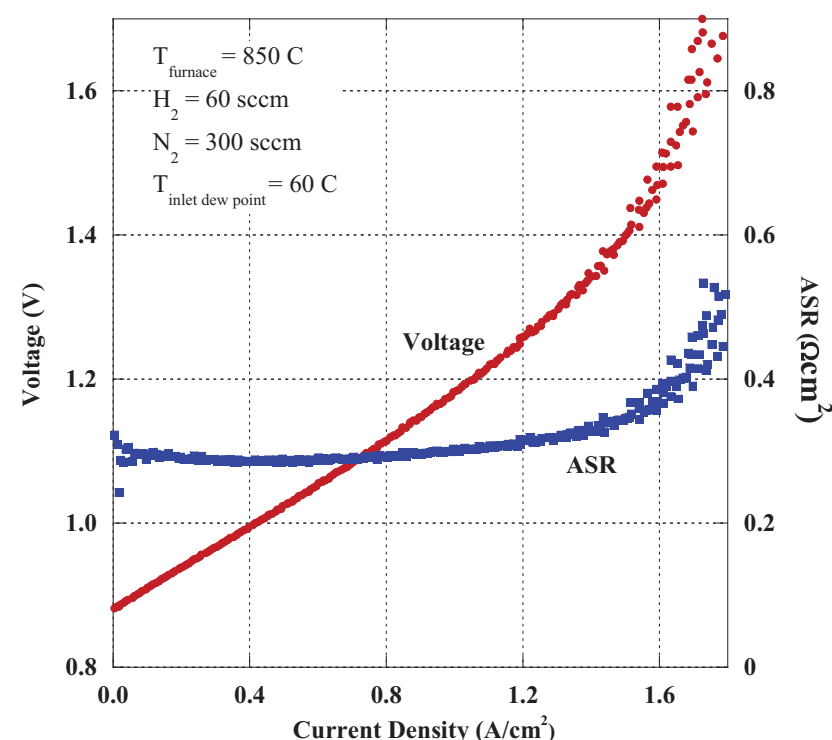

Figure 7. Polarization curve and respective ASR values for NASA cell 3.

Figs. 7 and 8 show voltage sweep / polarization curve test results for NASA cell 3. This test used a higher inlet steam flow rate and thus could sustain a significantly higher current density before becoming steam starved. For this cell and these test conditions, starvation was not noted until current densities in excess of $1.4 \mathrm{~A} / \mathrm{cm}^{2}$, or steam utilizations of $30 \%$ and greater. ASR values for this cell were roughly the same as for cell 1 .

Test results for cell 5 are found in Fig. 9. This cell was tested in the newly refurbished testing apparatus. In this case, the voltage sweep extended slightly into the fuel cell range of operation. The lower limit for the voltage sweep was determined

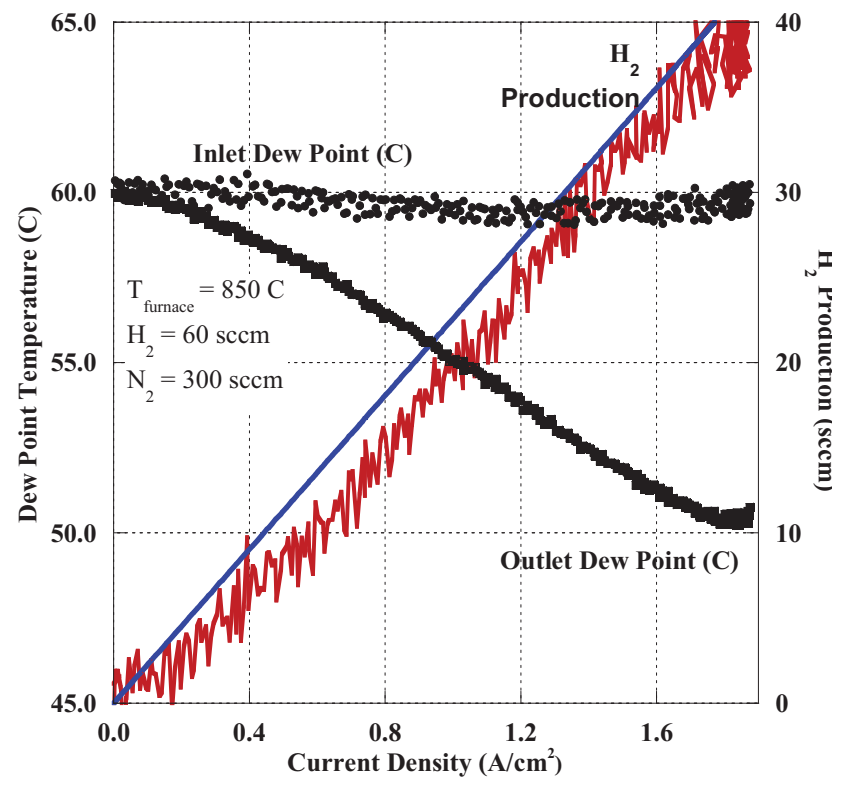

Figure 8. Dew points and $\mathrm{H}_{2}$ production rates for polarization curve in Fig. 7.

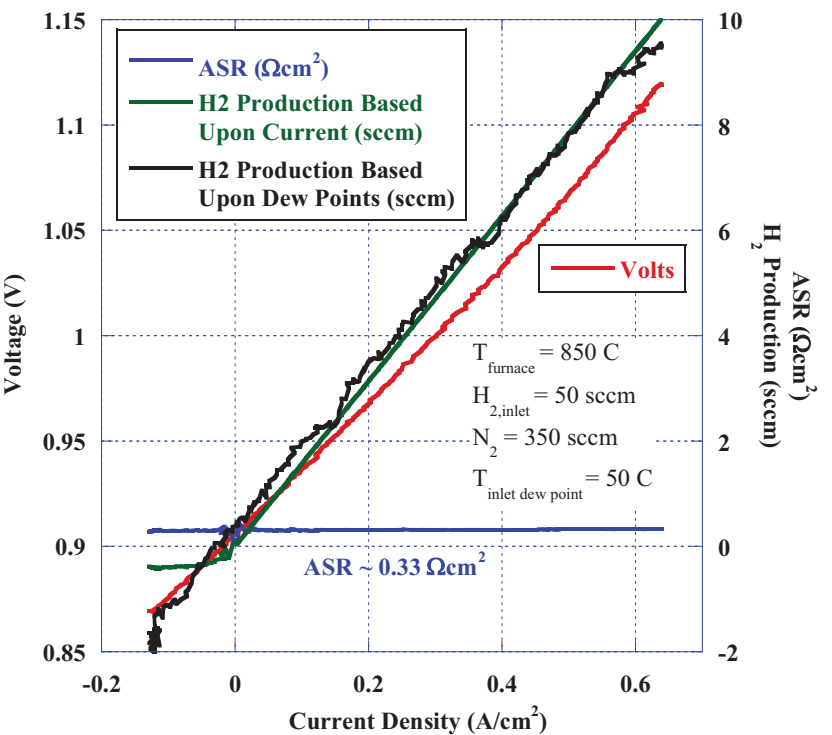

Figure 9. Polarization curve and $\mathrm{H}_{2}$ production rates for NASA cell 5 .

by the ability of the power supply to sink the current produced by the cell. The resulting polarization curve remained linear through zero current density, indicating low activation polarization. The average ASR for the sweep was $0.33 \Omega \mathrm{cm}^{2}$.

NASA cell 7 was the most extensively characterized of the cells tested to date. Two initial voltage sweeps / polarization curve tests were performed, after which the cell was allowed to run in a steady state, long duration mode for over 420 hours. During this extended period of operation, three additional voltage sweeps were performed: at 20 hours, 40 hours, and 80 hours elapsed test time. Fig. 10 summarizes the voltage sweeps. The first sweep was run for an inlet dew point of $50 \mathrm{C}$, whereas the

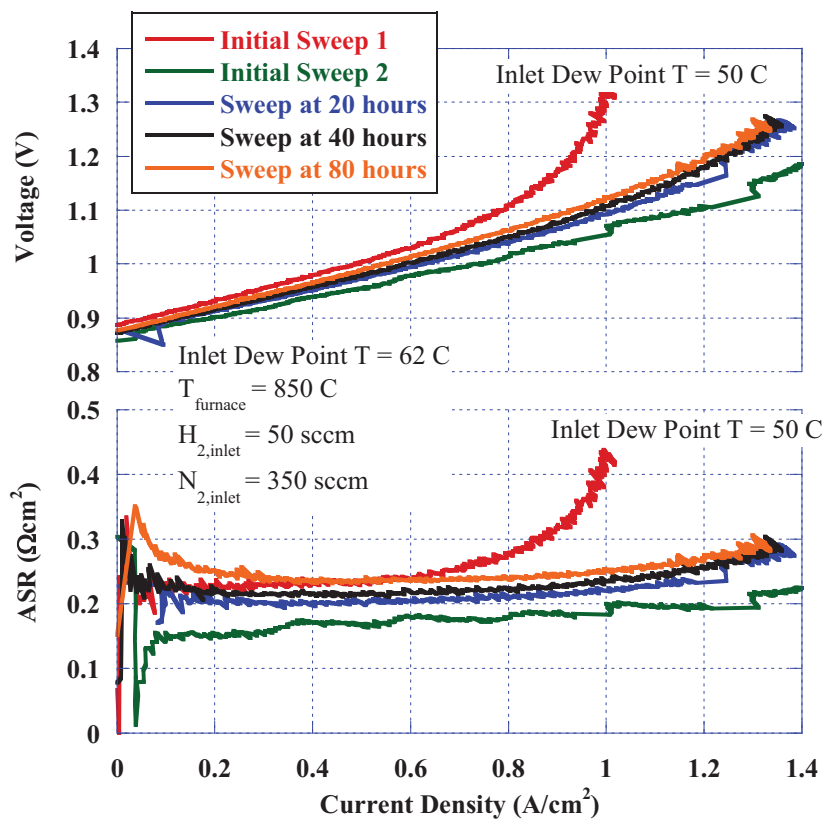

Figure 10. Summary of polarization curves for NASA cell 7 


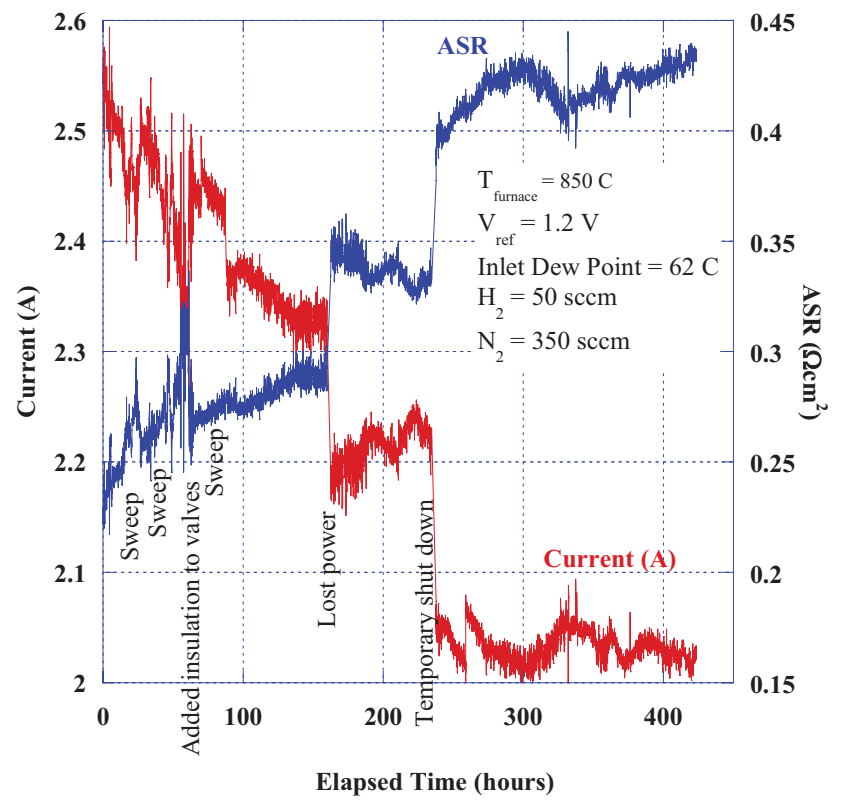

Figure 11. Long duration test data for NASA cell 7.

inlet dew point temperature for the remaining sweeps was $62 \mathrm{C}$. Steam starvation was only observed in the first (low inlet dew point temperature) sweep. Comparison of the four subsequent voltage sweep shows that the ASR values gradually deteriorated with time, indicating a slow degradation in cell performance.

Fig. 11 presents the long duration test data for NASA cell 7. After initial characterization, the cell voltage was set to 1.2 volts. The test was continued for 420 hours. Three voltage sweeps / polarization curves were generated during long duration testing, as indicated on the figure. Three other perturbations occurred during long duration testing. At 64 hours long-term test duration additional heat trace heaters and insulation were added around some valves in the test apparatus. This was done to prevent the formation of condensation, and seemed to temporarily improve the cell ASR. At 160 hours elapsed test time there was a loss of facility power. Since the computer for the data acquisition system was not powered via an uninterruptible power supply, there was a loss of control and the cell furnace cooled about 150 $\mathrm{C}$ to $700 \mathrm{C}$. This disruption caused the cell ASR to climb from $0.28 \Omega \mathrm{cm}^{2}$ to $0.34 \Omega \mathrm{cm}^{2}$. The cell did recover somewhat, but at 235 hours test duration the computer lost communication with the data acquisition system due to a faulty cable. This again required several hours to repair, during which time the furnace cooled to $550 \mathrm{C}$. During this period, the cell ASR deteriorated from $0.33 \Omega \mathrm{cm}^{2}$ to $0.4 \Omega \mathrm{cm}^{2}$. The loss of power and the loss of communications were the dominant contributors to degradation in the cell's performance.

The NASA cells were designed as fuel cells. However, the cells performed quite well as steam electrolyzers. Depending, of course, upon inlet steam flow rate, the cells can handle quite high current densities. Initial performance, as measured by ASR values, was good. More long duration tests are planned for the future to characterize cell degradation.

\section{CONCLUSIONS}

The INL, in collaboration with NASA, has been actively researching the use of solid oxide cells for high temperature electrolysis of steam for $\mathrm{H}_{2}$ production. Testing to date of a novel cell design by NASA has shown good initial power-to-weight performance and relatively low degradation in performance over time. Solid-oxide-based high temperature electrolysis seems to be a promising technology for efficient large-scale production of $\mathrm{H}_{2}$.

\section{ACKNOWLEDGMENTS}

This work was supported by the U.S. Department of Energy, Office of Nuclear Energy, Nuclear Hydrogen Initiative Program. The Idaho National Laboratory is operated for the U.S. Department of Energy's Office of Nuclear Energy by the Battelle Energy Alliance under contract number DE-AC07-05ID14517. Special thanks to Mr. John Setlock at NASA GRC for fabrication of all of the NASA cells.

\section{REFERENCES}

Hirsch, R.L., Bezdek, R., Wendling, R., "Peaking of World Oil Production: Impacts, Mitigation, \& Risk Management,“ United States of America Department of Energy NETL Report February, 2005.

Sandalow, D., Freedom From Oil, McGraw-Hill, New York, NY, 2008.

Scott, David Sanborn, Smelling Land: The Hydrogen Defense Against Climate Catastrophe, QPBooks, May, 2008.

Yildiz, B., and Kazimi, M. S., "Nuclear Energy Options for Hydrogen and Hydrogen-Based Liquid Fuels Production," MIT-NES-TR-001, September 2003.

Stoots, C., O'Brien, J., Herring, J., and Hartvigsen, J., "Syngas Production via High-Temperature Coelectrolysis of Steam and Carbon Dioxide," Journal of Fuel Cell Science and Technology, Vol 6, February, 2009. 